\title{
Soós Aladár professzor munkássága a modern táplálkozástudomány perspektívájából
}

\author{
Molnár Szilvia $^{1}$ - Csajbókné dr. Csobod Éva ${ }^{2}$ - Solymosi Dóra dr. ${ }^{3}$ \\ 'Semmelweis Egyetem, Egészségtudományi Kar, Alkalmazott Egészségtudományi Intézet, \\ Dietetikai és Táplálkozástudományi Tanszék, Rácz Károly Doktori Iskola, Egészségtudományok, Budapest \\ ${ }^{2}$ Semmelweis Egyetem, Egészségtudományi Kar, Alkalmazott Egészségtudományi Intézet, \\ Dietetikai és Táplálkozástudományi Tanszék, Budapest \\ ${ }^{3}$ Semmelweis Egyetem, Rácz Károly Doktori Iskola, Klinikai Orvostudományok, Budapest
}

A táplálkozás életünk fennmaradásának egyik fontos eleme, örömforrás, társadalmi, családi esemény, ünnep, napi szükséglet, az egészség alapfeltétele, elősegítője vagy tönkretevője, s napjainkban egyre inkább aggodalmak tárgya, sajnos, nem alaptalanul.

Az utóbbi években a krónikus, vagy más néven a civilizációs betegségek tömeges elterjedésének vagyunk tanúi a fejlett és egyre inkább a kevésbé fejlett országokban egyaránt, annak ellenére, hogy az orvostudomány rohamosan fejlődik. A civilizációs betegségek, mint a nevük is jelzi, az ipar rohamos fejlődésének, a modernizációnak, a civilizációnak negatív velejárói $[1,2]$.

A civilizációs betegségek közé sorolható a túlsúlyosság és az elhízás, amelyek további krónikus, nem fertőző betegségek potenciális okozói lehetnek. Idetartoznak a szív- és érrendszeri betegségek, a rosszindulatú daganatok és nem utolsósorban a cukorbetegség és szövődményei $[3,4]$. Az eddig csak nők körében terjedő, „néma járványként" emlegetett csontritkulás a férfiak körében is egyre gyakoribb $[5,6]$. A krónikus betegségek kialakulásában - számos egyéb tényező mellett - óriási szerepe van a helytelen táplálkozásnak [7]. Bizonyított, hogy nemcsak a hiányos, hanem a túlzott tápanyagbevitel, sőt összességében a helytelen táplálkozási attitûd, a civilizációs betegségek kialakulásában 40-60\%-ban tehető felelőssé [8]. Sajnos hazánk sem kivétel a fentiek alól. Sőt, élen járunk számos civilizációs megbetegedést illetően. A mai Magyarországon a vezető halálokok $80 \%$-át a nem fertőző krónikus betegségek - a szív- és érrendszeri, valamint a daganatos megbetegedések - adják [9].

Meglátásunk szerint a prevenció, a táplálkozásra való nagyobb odafigyelés lehetne a lehető leggazdaságosabb és legoptimálisabb megoldás a rohamosan romló népegészségügyi mutatók javítására, a dráguló egészségügyi ellátás kiváltására. Természetesen ez a gondolat csak megfogalmazásában új, hisz az emberek táplálkozása - akár egészséges, akár beteg egyénről legyen szó - már a tudomány ókori múvelőit is foglalkoztatta. Közülük néhányan az egyénre szabott diéta fontosságát is hangsúlyozták. Hippokratész (i. e. 460-377) azzal a véleményével, miszerint táplálkozási tanácsot az egész ember természet adta jellegzetességeiből kiindulva érdemes adni, figyelembe véve minden egyes étel és ital szervezetre gyakorolt hatását, lefektette az individuális táplálkozás alapjait [10]. Az ókori görög orvos erről így ír „,Az étrendről" címú munkájában [11], mely Oláh Andor fordításában magyarul is olvasható: „...ha lehetővé válik, hogy minden egyéni természet számára megtaláljuk a táplálék megfelelő mértékét ... ha sem túlzásba nem esünk, sem hiányt nem szenvedünk, akkor megtaláljuk az egészség fenntartásának helyes módszerét”.

A betegségek étrendi kezelésének gondolata elődeinket a reformkorban is foglalkoztatta. A pesti orvosi kar medikusa, Koppel Zsigmond - később zágrábi gyakorló orvos - latin nyelvú orvosavató értekezést jelentetett meg 1833-ban „...de morborum cura diaetetica” címmel. „A betegségek diétás kezeléséről” írt 34 oldalas dolgozat második része ismerteti az ókori Celsustól a kortársakig megjelent legfontosabb diétás módszereket [12].

Magyarországon a szervezett diétás kezelés tényleges elindítója Soós Aladár (1890-1967) professzor volt. Példa nélküli munkájának köszönhetően megszervezte a klinikai élelmezést és ezen belül az individuális betegellátást, valamint megalapozta a diétás szakemberek képzését. Kiválóságát mutatja, hogy abban az időben, 1922-ig, egyedül Amerikában volt ismeretes az orvosi munkában segítséget nyújtó diétás munkaerő fogalma. Felismerte az egyéni betegellátás jelentőségét, az ételeknek a betegség és a beteg igényei szerinti megválasztásának fontosságát [13]. 


\section{Dr. Soós Aladár életútja}

Soós Aladár professzor 1890. január 19-én, Egerben született. Középiskolai tanulmányait Kassán (ma: Košice, Szlovákia), a Premontrei Gimnáziumban végezte, majd 1907-ben tett érettségi vizsgát. A Budapesti Királyi Magyar Tudományegyetemen (ma: Semmelweis Egyetem) [14] 1912-ben szerezte meg orvosi diplomáját. Gyakorlati évét a Rókus Kórházban töltötte Herczel Manó professzor mellett, végül pedig Korányi Sándor belgyógyászati klinikájára, a III. sz. Belklinikára került, ahol 1914 márciusában díjtalan gyakornokká nevezték ki. A Klinika a komfortosabb kórtermek igénybevételét díj ellenében tette lehetővé a pácienseknek, az így befolyt összeget pedig a díjtalan gyakornokok között osztotta szét. Hamar tanársegédi posztot kapott a fiatal Soós doktor, mely nemcsak tudományos, hanem anyagi előrelépést is jelentett. Rövidlátása miatt felmentették a katonai szolgálat alól, így az első világháború alatt a Klinikán látta el feladatait. Korányi professzor igazi mentorként a dietetika felé irányította Soós doktor figyelmét, és lehetővé tette számára a külföldi tanulmányutakat, így 1919 őszén több hónapon át a berlini Kraus-klinikán, utána a drezdai Weidner-szanatóriumban dolgozhatott. Gyakorlati ismereteket szerzett a diétás konyhatechnikában, és elmélyítette táplálkozástudományi ismereteit. Amikor 1921-ben hazatért, a Klinika fizioterápiás és dietetikai osztályának a megszervezésével bízták meg. Létrehozott egy új betegélelmezési szisztémát, az egyéni igényeket figyelembe vevő individualizálórendszert, amely választásos étrendet biztosított [15-17] az addigi kötött menürendszer helyett. A Klinikán 1922-ben készített fénykép Soós doktort életművéhez illeszkedően, étkezés közben örökítette meg (1. ábra) [18].

Soós Aladár doktor 1923-ban tartott először „főzőtanfolyamot” orvosok részére. Brauer professzor meghívására 1924-ben Hamburgban, az eppendorfi klinikán, dietetikai osztályt szervezett. Ugyanabban az évben megjelent a „Diétáskonyha technikája” című munkája, előbb magyarul Budapesten, majd németül Hamburgban. Az „Étrendi előírások a gyakorlatban” címú könyve először 1925-ben jelent meg (2. ábra) [19], amelyet még öt kiadás követett. A szerző a mentorának ajánlotta múvét: „Életalakító éveim emlékére ajánlom e lapokat tanító Mesteremnek báró KORÁNYI SÁNDOR profeszszor úrnak hálatelt szívvel és tanítványi ragaszkodással.” „A belső betegségek diétás kezelése és annak technikája” tárgykörből 1925-ben egyetemi magántanárrá habilitálták. Megalkotta az úgynevezett elixrendszert, amelyet számos európai országban bevezettek. A rendszer lényege abban rejlett, hogy évszakonként kidolgozta az élelmiszerek árlistáját és a választott diéta elkészítéséhez szükséges munkaidőt. A kettő adta az elixértéket. Így az egyszerúbben elkészíthető ételekből az adag nagysága nagyobb volt, mint a több időt igénybe vevő ételekből. Külföldön is felfigyeltek munkásságára, és Németország, Svájc, Svédország, Dánia számos kórházában kezdték al-

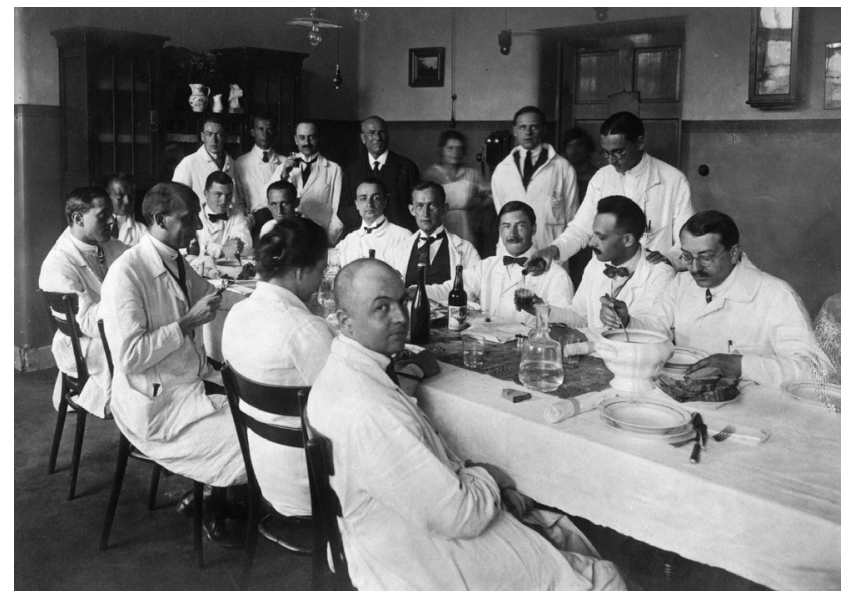

1. ábra | Dr. Soós Aladár - jobb szélen, éppen levest szed (forrás: [18])

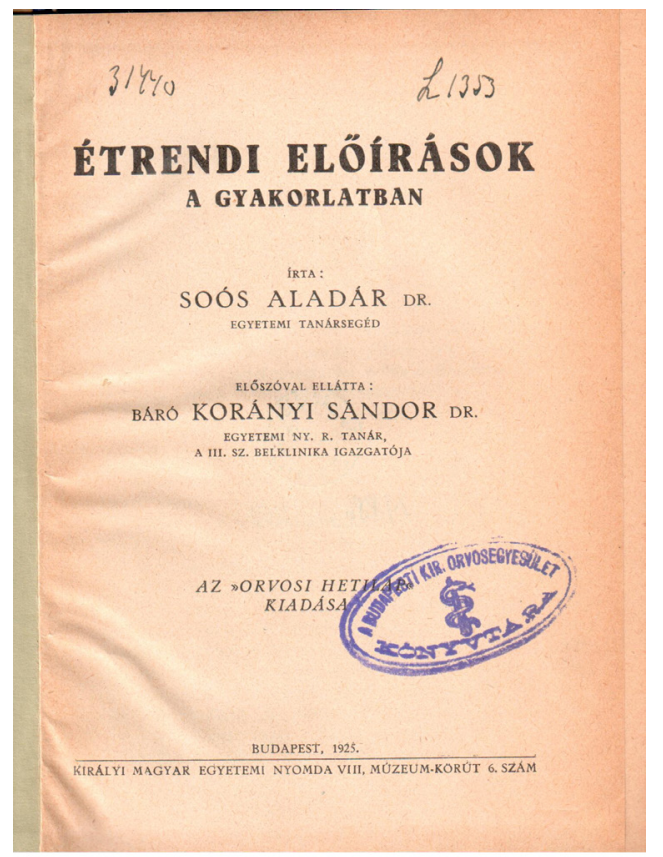

2. ábra $\quad$ Az első kiadás (forrás: [19])

kalmazni az általa kidolgozott eljárásokat. Jürgensen dán professzor Soós rendszerét „Budapest System”-nek nevezte. Klebelsberg Kunó kultuszminiszter 1927 nyarán az egyetemi klinikák betegélelmezésének teljes átszervezésével bízta meg. Tapasztalatairól 1929-ben a Nemzetközi Kórházszövetségnek Atlantic Cityben, majd 1930ban a Gesellschaft für Verdauungskrankheiten budapesti konferenciáján számolt be. 1930. október 28-a különösen jelentős dátum, hiszen dr. Soós Aladárt az újonnan létesített egyetemi Dietetikai Intézet igazgatójává nevezték ki. Feladatkörét az Intézetben 23 éven át, 1953-ig látta el igaz becsülettel, hatalmas tudással és alkotókedvvel. 1931. június 10-én a Nemzetközi Kórházszövetség dietetikai szakosztályának elnöke lett. 1932-ben útjára indult a Magyar Kórház című szaklap, amelynek 13 éven keresztül szerkesztője volt. Ebben az időben Budapesten 
és Kecskeméten élelmezéstechnikai tanfolyamokat szervezett. Diétás szakembereket képzett, nagy hangsúlyt fektetve a gyakorlatokra is. Szerteágazó feladatai ellenére sem hagyta abba az egyetemi oktatást, hétfő délutánonként heti két orában hallgathatták óráit a Királyi Magyar Pázmány Péter Tudományegyetem polgárai [20]. 1935. december 19-én kötött házasságot Komjáthy Gabriellával (1909. szeptember 4. - ?). Két gyermekük született [21]. Lipcsében 1936-ban kiadták a „Verpflegungsbetrieb" címú kötetét, melyben az élvezeti értékek előtérbe állításával kidolgozta az egyéni betegélelmezés alapjait. A második világháború után saját házában rendezett be tankonyhát, itt a diétás nénéket képezte, s ezt a későbbiekben az Országos Élelmezés- és Táplálkozástudományi Intézetben is folytatta. Tarján Róbert professzor, az Országos Táplálkozás- és Élelmezéstudományi Intézet (ma: Országos Gyógyszerészeti és Élelmezés-egészségügyi Intézet) igazgatója 1953-ban arra kérte, hogy vegye át az intézet dietetikai osztályának vezetését, ahol nyugdíjazásáig, 1957-ig dolgozott. Utolsó munkája 1966-ban jelent meg, amelyben a zamatérzet jelentőségéról tárgyalt. „A zamatérzet, az élelem élvezeti értékének szubjektív alapja, táplálékunk nemesítésének eredménye." Megérte, hogy a diétásnéne-képzés 1957-től az Állami Diétásnővérképző Iskolában kétéves képzés keretében folyt, s hogy az orvosi egyetemen 1964-ben dr. Rigó János vezetésével megalakult az önálló költségvetésú dietetikai tudományos munkacsoport, amelynek feladata az egyetem dietetikai rendszerének és élelmezésének megszervezése volt. Soós Aladár 77 éves korában, 1967. október 2-án hunyt el. Belföldön és külföldön 127 önálló előadást tartott, 81 közleménye jelent meg [13-17, 22, 23].

\section{Soós Aladár életmúve, egészségnevelő hagyatéka}

Soós Aladár professzor munkásságának kimagasló érdeme az a felismerés, hogy a dietoterápiás feladatok ellátása, a betegek élelmezése - speciálisan képzett - szakembert igényel, aki szakmai ismereteinek birtokában összekötő szerepet tölt be a beteg, az orvos és a konyha között. Feladata, hogy a betegeknek olyan diétás ellátásról gondoskodjon, amely egyénre szabottan biztosítja gyógyulásukat. Ennek érdekében megszervezte - az Egyesült Államok után másodikként a világon - a „diétás nénék”, a későbbiekben „diétás nővérek”, majd „dietetikusok" képzését. A képzés színvonalát jellemezte, hogy az okleveleket az országos tiszti fóorvos látta el kézjegyével [22].

A nemzetközileg is elismert képzés keretein belül elsősorban az egészséges táplálkozást igyekezett hallgatóival megismertetni. A magyar konyhatechnikát kívánta az ugyancsak nemzetközileg elismert francia konyhamúvészettel párosítani. Hasonló törekvései voltak a kórházi dietoterápia alkalmazásakor is. Erről így nyilatkozott: „A diétás konyhatechnika feladata az lesz tehát, hogy a finom, franciás konyhatechnikai eljárásaival tegye a nemzeti vagy házi kosztot ízletesebbé, étvágyingerlővé, finomabbá, vagyis dietetikailag kedvezőbben megítélhetővé" [13].

Soós Aladár abból indult ki, hogy a kórházba került beteg, aki kiszakad otthoni környezetéból, mindenképpen szenved. Ezt a rossz közérzetet az egyéni kívánságokat figyelembe vevő élelmezéssel enyhíteni lehet, mely így amellett, hogy csökkenti a beteg diszkomfortérzését, hatásosabb gyógytényezővé is válik [13-17, 22, 23].

"A nagy konyha mint ételgyár" címú munkájában hangsúlyozza, hogy „a konyha a mennyiségből minőséget állít elő, s ezáltal a konyhákon értéktermelés folyik. Nem közömbös, hogy egy nagykonyha jobb minőségú élelmet szolgáltat azonos költségből, vagy ha magas színvonalon dolgozik, ugyanazt a minőséget olcsóbban tudja elóállítani” [17].

Tanfolyamokat szervezett az orvosok számára is, hogy megértsék a dietetika fontosságát. Elkezdett munkássága a kórházi élelmezés korszerüsítése és a szakemberek képzése területén tovább folytatódott 1971-tól a Dietetikai Tudományos Munkacsoportból szerveződött Országos Dietetikai Intézet és a Magyar Dietetikusok Országos Szövetsége hagyományőrző, a korszerü dietetikai szempontokat ismertető munkájában, majd 1975 szeptemberétôl előbb a hároméves, később a négyéves dietetikusi, továbbá az élelmezésvezetői és az élelmezésmenedzseri képzésekben $[15,16]$.

A Magyar Dietetikusok Országos Szövetségének elnöksége 1992-ben Soós Aladár-emlékérmet alapított a dietetika kiemelkedő múvelőinek elismerésére. Az a tény, hogy 2008-ban bronzba öntött arcképe a Semmelweis Egyetem tizenkét neves orvosa közé került, méltó emléket állít az orvosprofesszor életmúvének $[13,16]$.

\section{Összegzés}

Soós Aladár professzor nemzetközileg is széles körben elismert munkásságára jellemző, hogy megállapításai a XXI. században is naprakészek, modernek. Napjainkban, amikor divatossá váltak a különböző táplálkozási irányzatok, amikor félrevezető hirdetések sora árasztja el a médiát, nagy szükség van arra, hogy tudományosan felkészült táplálkozási és élelmezési szakemberek mutassák a helyes utat, lássanak el közétkeztetési feladatokat.

A terület szakmai elvárásai kiszélesedtek, a táplálkozástudomány és a dietetika szerepe fokozatosan megnövekedett. Olyan szakemberek képzése vált szükségessé, akik a gyógyító team tagjaként alkalmasak a dietoterápia önálló múvelésére, a korszerúsödő élelmezési üzemek vezetésére, és részt vállalnak a lakosság egészségesebb táplálkozási szokásainak kialakításában [22,23].

Az egészséges táplálkozás népszerúsítése, tudatosítása pedig nem „kampányprogram”, hanem folyamatos köznevelési feladat, amely minden generációt érint, hiszen a dráguló egészségügyi ellátás kiváltására sokszor a megelőzés, a helyes táplálkozás lehetne a megoldás. 


\section{Irodalom}

[1] Nichols M, Townsend N, Scarborough P, et al. Cardiovascular disease in Europe 2014: epidemiological update. Eur Heart J. 2014; 35: 2950-2959.

[2] Health Report - 2016. Information on identifying target areas for public health interventions based on analysis of non-communicable diseases and health behavior indicators. [Egészségjelentés, 2016. Információk a népegészségügyi beavatkozások célterületeinek azonosításához a nem fertőző betegségek és az egészségmagatartási mutatók elemzése alapján.] Nemzeti Egészségfejlesztési Intézet, Budapest. Available from: http://www. egeszseg.hu/szakmai_oldalak/assets/cikkek/17-05/egeszsegjelentes-2016.pdf [accessed: January 2017]. [Hungarian]

[3] Kyrou I, Randeva HS, Tsigos C, et al. Clinical problems caused by obesity (updated: January 11, 2018). In: De Groot LJ, Chrousos G, Dungel K, et al. (eds.) Endotext. MDtext.com, South Dartmouth, MA, 2000. Available from: https://www. ncbi.nlm.nih.gov/books/NBK278973/\#_NBK278973_pubdet [accessed: July 24, 2018]

[4] Engin A. The definition and prevalence of obesity and metabolic syndrome. Adv Exp Med Biol. 2017; 960: 1-17.

[5] Bhattoa Harjit P, Balogh Á. Factors influencing the incidence of male osteoporosis and their vitamin D supply. [A férfiosteoporosis előfordulási gyakoriságát befolyásoló tényezők és D-vitaminellátottságuk vizsgálata (A Magyar Osteoporosis és Osteoarthrologiai Társaság [MOOT] 18. kongresszusa).] Ca \& Csont 2009; 12: 57-76. [Hungarian]

[6] Osteoporosis in men. NIH Osteoporosis and Related Bone Diseases - National Resource Center (last reviewed: October 2018) NIH Pub. No. 18-7885-E. Available from: https://www.bones. nih.gov/health-info/bone/osteoporosis/men\#b [accessed: August 27, 2019].

[7] Biró Gy. The effects of national fat consumption on public health. [A hazai zsiradékfogyasztás változásának közegészségügyi hatásai.] Élelmezési Ipar 2008; 62: 137-141. [Hungarian]

[8] Antal E. Illnesses of civilization: What can we do? [Civilizációs betegségek: mit tehetünk ellenük?] Élelmiszer, Táplálkozás és Marketing 2007; 4: 37-40. [Hungarian]

[9] Kovács ME, Mészáros E. Quality of life and burden of disease in the most common diseases affecting the Hungarian population according to Hungarostudy 2002. In: Kopp M, Kovács ME. (eds.) Quality of life of the Hungarian population at the turn of the millennium. [Életminőség és betegségteher a magyar lakosságot érintő leggyakoribb betegségekben a Hungarostudy 2002 adatai alapján. In: Kopp M, Kovács ME. (szerk.) A magyar népesség életminősége az ezredfordulón.] Semmelweis Kiadó, Budapest, 2006; pp. 412-420. [Hungarian]

[10] Balázs P. The source of the mythology of secular medicine. In: Medicine for money and for the sense of vocation. [A világi orvoslás mitológiájának forrása. In: Orvoslás pénzért és hivatástudatból.] Melánia Kiadó, Budapest, 2002; pp. 89-99. [Hungarian]
[11] Sellö T. (ed.) Communications from the library of Hungarian medical history, Vol. 38-39. [Communicationes ex Bibliotheca Historiae Medicae Hungarica 38-39. kötet.] Budapest, 1966. [Hungarian]

[12] Dörnyei S. Old Hungarian doctoral dissertations 1772-1849. Vol. I. [Régi magyar orvosdoktori értekezések 1772-1849. I. kötet.] Borda Antikvárium, Budapest, 1998. [Hungarian]

[13] Rigó J. Prides - Dr. Aladár Soós, creator of the dietetic system. [Büszkeségeink - Dr. Soós Aladár, a dietetikai rendszer megalkotója.] Új Diéta 2007; 34(3-4): 23. Available from: http:// www.ujdieta.hu/index36ff.html? content $=637$ [accessed: October 8,2019 ]. [Hungarian]

[14] Molnár L. The names of our university. [Egyetemünk elnevezései.] Orvosegyetem 1993; 7-8: 9. [Hungarian]

[15] Vértes L. The dietitian Dr. Aladár Soós's life's work in health education. [Dr. Soós Aladár dietetikus, egészségnevelő életmúve.] Egészségnevelés 1997; 38: 44-46. [Hungarian]

[16] Rigó J. In memoriam Aladár Soós (1890-1967). [In memoriam Soós Aladár (1890-1967).] Orv Hetil. 1967; 108: 2533-2534. [Hungarian]

[17] S. Deli M. In memoriam Aladár Soós. [Soós Aladár emlékezete.] Orv Hetil. 1987; 128: 2642. [Hungarian]

[18] Personal documents of Tibor Győri (1880-1938): Photo album showing the 3rd Department of Internal Medicine. [Györi Tibor (1880-1938) iratai: A III. sz. Belklinikát bemutató fényképalbum.] Semmelweis Egyetem, Budapest, 1922. Központi Levéltár, 302.d.9. [Hungarian]

[19] Soós A. Dietary menu requirements in practice. [Étrendi elő́rások a gyakorlatban.] Az Orvosi Hetilap kiadása, Budapest, 1925. [Hungarian]

[20] Curriculum of the Royal Hungarian University of Budapest for 1934-1935 and 1938-1939 school years. [A Budapesti Királyi Magyar Tudományegyetem tanrendje az 1934-1935. és az 1938-1939. tanévre.] Semmelweis Egyetem, Központi Levéltár, Budapest. [Hungarian]

[21] Geni - Family tree research website. Available from: https:// www.geni.com [accessed: October 4, 2019].

[22] Gaálné LK. Pre-college education, Diet nurse courses. [A fóiskolai képzés előzményei, Diétásnővér szaktanfolyamok.] Jubileumi Évkönyv 1975-2000. Semmelweis Egyetem, Egészségügyi Föiskolai Kar, Budapest, 2000. [Hungarian]

[23] Németh I. Analysis of dietetic training programs. Doctoral thesis. [Dietetikus képzési programok elemzése. Doktori értekezés.] Semmelweis Egyetem, Patológiai Doktori Iskola, Budapest, 2011. Available from: http://phd.sote.hu/mwp/phd_live/vedes/export/nemethistvanne.m.pdf [accessed: October 4, 2019]. [Hungarian]

(Molnár Szilvia, Budapest, Vas u. 17., 1088 e-mail: molnar.szilvia@se-etk.hu)

A cikk a Creative Commons Attribution 4.0 International License (https://creativecommons.org/licenses/by/4.0/) feltételei szerint publikált Open Access közlemény, melynek szellemében a cikk bármilyen médiumban szabadon felhasználható, megosztható és újraközölhető, feltéve, hogy az eredeti szerző és a közlés helye illetve a CC License linkje és az esetlegesen végrehajtott módosítások feltüntetésre kerülnek. (SID_1) 